\title{
A HAZARD CONNECTED WITH RE-USE OF THE BAIN'S CIRCUIT: A CASE REPORT
}

\author{
R. HANNALLAH, M.D., F.R.C.P.(C) AND J.K. Rosales, M.D., F.R.C.P.(C) ${ }^{\circ}$
}

\section{INTRODUCTION}

The STREamLined Modification of Mapleson's D circuit recently described by Bain \& Spoerel ${ }^{1}$ has been used for older children in our hospital. We find its light weight and length very convenient, especially for operations around the head. We found that with controlled ventilation the fresh gas flow of $70 \mathrm{ml} / \mathrm{kg}$ recommended by $\mathrm{Bain}^{2}$ resulted in near normal arterial $\mathrm{PacO}_{2}$. However, with spontaneously breathing patients it is the minute ventilation of the patient rather than the fresh gas flow that determines the $\mathrm{PaCO}_{2}$ provided enough flow is used to wash $\mathrm{CO}_{2}$ from the circuit itself. This is true even if a non-rebreathing system such as the Fink valve is used. As most of our patients receive a narcotic premedication, respiration usually has to be assisted or controlled regardless of the circuit used. Although the Bain's circuit is supplied as a sterile disposable unit, $f$ we wash and re-use it for reason of economy. The following case report describes events associated with an anaesthetic in which a previously used and washed Bain's circuit was used.

\section{CASE History}

A 14-year-old girl was scheduled for surgical correction of thoracic idiopathic scoliosis. Preoperatively, there were no signs or symptoms of abnormal lung function. Vital capacity, functional residual capacity and total lung capacity were within normal limits. Arterial blood gases were not checked.

Preoperative medication consisted of pentobarbitone $100 \mathrm{mg}$ two hours preoperatively, and morphine $4 \mathrm{mg}$ with scopolamine $0.4 \mathrm{mg}$ one hour later.

Induction of anaesthesia was accomplished by $5 \mathrm{mgm}$ of droperidol, $100 \mathrm{mcg}$ of fentanyl, followed by $200 \mathrm{mgm}$ of thiopentone intravenously. The trachea was sprayed with 10 per cent lidocaine, and a cuffed \#7 Magill Portex tube was introduced after $30 \mathrm{mgm}$ of d-tubocurare had been given. The patient was turned prone on bolsters, and anaesthesia was maintained using a flow of $4: 2$ nitrousoxide:oxygen delivered through a Bain's circuit. Ventilation was controlled using a volume cycled Blease ventilator. Increments of fentanyl and d-tubocurare were given as required. As this was amongst the first cases in which the Bain's circuit had been used an arterial blood gas sample was drawn one half hour after induction. There had been no change in vital signs; blood pressure and pulse had been maintained at exactly the pre-anaesthesic level in spite of moderate blood loss which had not been replaced. The cardio-scope showed sinus rhythm. The blood gases were $\mathrm{PCO}_{2} 122$ torr, $\mathrm{H}^{+}$100, B.E. - 8.0. Ventilation was rechecked in both

-Department of Anaesthesia, Montreal Children's Hospital, and McGill University, Montreal, P.Q., Canada.

†Respiratory Care Inc, 2420 East Oakton Street, Arlington Heights, Illinois 60006, U.S.A. 
lungs, and it seemed adequate. Another blood sample was taken for re-check, and confirmed the previous findings. The system was then changed to include a circle carbon dioxide absorber.

Arterial blood gases one half hour later showed $\mathrm{PaCO}_{2} 27, \mathrm{H}^{+} 31$, B.E. $0.0 \mathrm{Oxy}-$ genation was adequate at all times. The rest of the anaesthetic was uneventful, and the only postoperative problem was prolonged drainage from the bone graft site.

Inspection of the Bain's circuit which had been used showed avulsion of the inner tube designed to carry the fresh gas flow, at the machine end of the circuit (Figure 1). This meant that the whole length of the outer tube had become dead space, leading to full rebreathing. Had that situation been allowed to continue for the whole of the six-hour operation, the result could have been disastrous. It is worthwhile stating that none of the classic signs of hypercapnia ${ }^{3}$ were observed, except that, in retrospect, the blood pressure had been well maintained in the face of moderate blood loss.

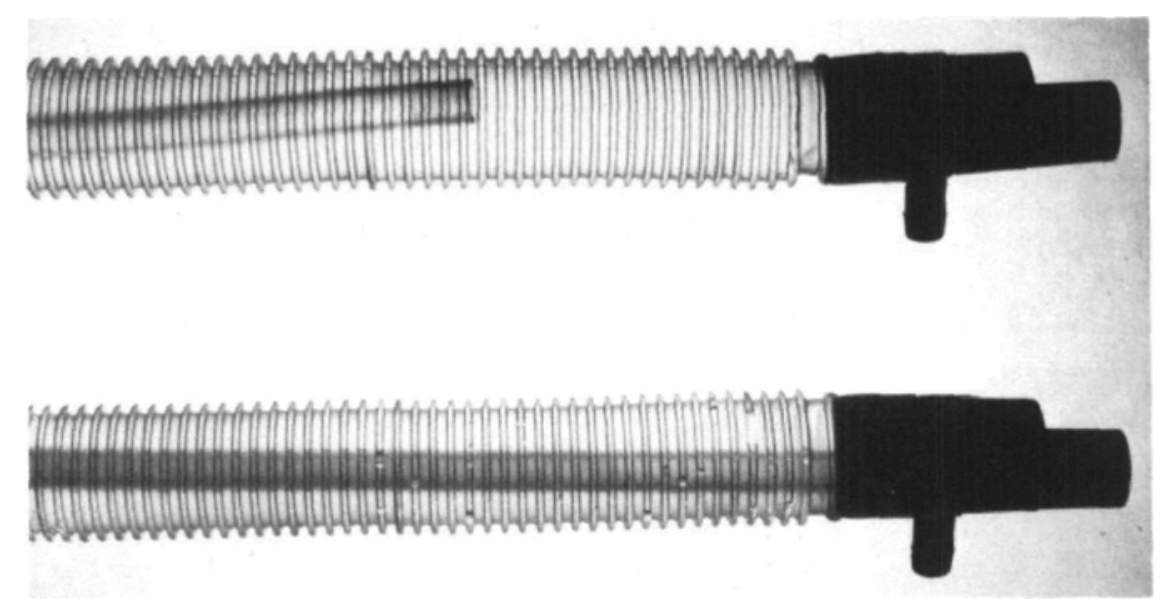

Figure 1. The broken Bain's circuit, compared with a new one. Note the avulsion of the inner tubing carrying the fresh gas flow at the machine end of the circuit.

\section{Discussion}

On examining how these circuits were washed and prepared for re-use in our department, it became obvious how this situation could have arisen. After washing the tube, the person in charge of equipment stretched the Bain's circuit in an attempt to drain out the excess water - a method that works well with single lumen rubber connecting tubes. But the inner tube of the Bain's, not being stretchable, disconnected from its mounting. We still wash and re-use our Bain's circuits, but we do not now stretch them, and we also inspect the inner tube before each use. We recommend that the outer tube should always be transparent to allow inspection of the connections, and for that very reason we feel that the newly introduced sets made of black conductive outer tubing $\$$ are hazardous.

†Advertising section, p. 69, Anaesthesiology, Jan., 1974. 


\section{SumMary}

A case of severe hypercarbia due to the use of a malfunctioning Bain's circuit is presented. Its manner of occurrence and its prevention are discussed.

\section{RÉSUMÉ}

Un enfant de 14 ans, développa une hypercarbie sévère au cours d'une anesthésie où fut employé un "circuit de Bain" défectueux. Le tube interne avait été disloqué durant le lavage et le séchage du circuit en vue de sa ré-utilisation. Ceci se produit lorsque le circuit est étiré pour en expulser l'eau. Il est recommandé que le tube externe soit toujours gardé transparent afin de faciliter l'inspection des joints avant chaque usage, et ainsi éviter cette complication.

\section{REFERENCES}

1. Bain, J.A. \& Spoerel, W.E. A streamlined anaesthetic system. Cdn. Anaes. Soc. J. 19: 426 (1972).

2. BAIN, J.A. \& Spoerel, W.E. Flow requirement for a modified Mapelson D. system during controlled ventilation. Cdn. Anaes. Soc. J. 20:629 (1973).

3. Phys-Roberts, C. Effects of hypercapnia. Gray, T.C. \& Nunn, J.F. General Anaesthesia, 3rd ed., London, Butterworths 1: 168 (1971). 